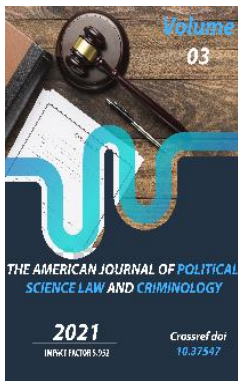

Journal Website: https://theamericanjou rnals.com/index.php/ta jpslc

Copyright: Original content from this work may be used under the terms of the creative commons attributes 4.0 licence.

\section{Negligence Vis-À-Vis Ignorance Of Fact With Reference To Responsibilities Of Investigative Officers}

\author{
Mahesh A. Tripathi \\ Phd Scholar, School Of Law, Humanities And Social Sciences, Rashtriya Raksha University, \\ Gandhinagar, Gujarat, India \\ Anand Kumartripathi \\ Pro- Vice Chancellor I/C \& Senior Assistant Professor Of Law, Rashtriya Raksha University, \\ Gandhinagar, Gujarat, India \\ Shahanshah Gulpham \\ Assistant Professor, School Of Criminology And Behavioural Science, Rashtriya Raksha \\ University, Gandhinagar, Gujarat, India
}

\title{
ABSTRACT
}

An investigative officer is the first stake holder of the criminal justice system who is responsible to bring each and every fact of the crime and to bring accused before the court of law. Sec- 328,Cr.P.C. emphasis on the inquiry of unsoundness of mind of an accused that believe to be suffering from any mental illness and a magistrate immediately directs prosecution for the a medical examination. If Magistrate is convinced that the person is of unsound mind and consequently incapable of making his defence, he shall postpone proceedings and referred the accused to the hospital for the treatment. Section- 100 to 105 of Mental Health Care Act, 2017 also laid down procedures to deal with mentally ill people who come in contact with law. However, it is found that investigative officers are either not aware of these criminal procedures or showing negligence towards it. Few cases of insanity were cometo notice by the Hon'ble High Courts where investigative officer's negligence resulted into miscarriage of judgments by lower courts. In this research article authors discussed few cases where Court has found lacuna's in investigative process and by setting past judgments aside deliver fresh judgment in the favour of an insane defendant. Researcher also explores the issue of human right violation by the criminal justice system itself. In conclusion some deliberations are made to eliminate such issues from criminal justice system.

\section{KEYWORDS}

Unsoundness of mind, investigation, mental illness, insanity, human right, criminal procedure. 


\section{INTRODUCTION}

Mental Health Care Act-2017 ${ }^{1}$ (MHCA), talks about the responsibilities of other agencies towards mentally ill person. In which Sec-100 defines the duties of police officers in respect of persons with mental illness. Furthermore, clause (3) of this section state that any person under protection shall be immediately taken to the nearest public health establishment as soon as possible for the assessment of healthcare needs and a mental health professional will evaluate and shall convey the findings to the incharge police officer. Sec -102 of the same Act further state that when any person with mental illness or who may have a mental illness appears or is brought before a Magistrate, he may order that the person is conveyed to a public mental health establishment for assessment and treatment. The mental health professional shall submit a report to the Magistrate and the person shall be dealt with in accordance with the provisions of this Act.

Section 328 to 330 of the Code of Criminal Procedure $(\mathrm{CrPC}-1973)^{2}$ defines the criminal proceedings against an accused that appears or bring to notice by the investigative officer that the person charged is not mentally sound ${ }^{3}$. Magistrate holds inquiry and if found reason to believe that the person against whom the inquiry is being held is of unsound mind and unable to make defence will direct for examination of mental status ${ }^{4}$. After receiving the report for the same if magistrate holds the opinion of unsound mind shall postpone the

\footnotetext{
${ }^{1}$ Mental Health Care Act.2017. Ministry of Law and Justice, New Delhi

${ }^{2}$ The Code of Criminal Procedure, 1973, Ministry of Law and Justice, New Delhi

3 Gaur J. R. and Tripathi, M. A. "Insanity, mental trauma, crime and the law", International Journal of
}

proceedings. Court may release the accused on sufficient security or may order the accused to be detained in safe custody at Government mental health care establishment.

As discussed above laws and criminal proceedings are well defined and discussed about how to deal with mentally ill people who come into conflict with law. These laws and criminal procedures are amended to reduce and remove the human right violation related issues that were noticed and apprehended by the High Courts and Apex court of the country time to time.

However, when comes to the implementation of these laws and proceedings, it seems that the basic pillars of the criminal justice system are still either unaware of these particular laws and proceedings or reluctant to follow the amended concepts. There negligence or ignorance towards it, raise severe human right violation related issues.Because no person to be held criminally responsible of the act in the eyes of a competent court till the contemporary is proved beyond reasonable doubt $^{5}$. Hence may not be proved guilty and may not be punished or sentenced.

Criminal justice process is depends on the prosecution and it is the duty and responsibility of an investigative officer to investigate each and every aspects of crime and accused. The public prosecutor is also a prominent person in criminal justice system who supposed to frame the charges against a person on the available facts. Both are getting enough time to submit a charge sheet against an accused person. Co-

Management and Social Science Research Review, 8, 12, (2021)

4 Tripathi, M. A. and Tripathi, A. K. Paradigm Shift in Indian Legislature with Reference to Criminal Responsibility of an Unsound Mind, "Pragyaan: Journal of Law" 10, 1, (2020)

${ }^{5}$ AIR 1970 All 51, 1970 CriLJ 132 
occurring disorders is also references for investigation in special cases $^{6}$.

The responsibilities of courts are also defined and there is no higher principle for the guidance of the court than the one that no act of courts should harm a litigant and it is the bounden duty of the courts to see that if a person is harmed by a mistake of the court he should be restored to the position he would have occupied, but for that mistake ${ }^{7}$. As per above discussion it is crystal clear that Indian Penal Code and Cr.P.C. both have enough provisions to deal effectively with mentally ill people. However, when comes to the implementation strong lacuna is noticed from investigation and prosecution part of the criminal justice system.

This research is aim to explore the existing problems and suggestion for the improvement in Criminal Justice Proceedings and as well in prosecution against mentally ill people. Researchers made a deliberate attempt to discuss two such cases where high court found severe mistakes from prosecution side.

\section{METHODOLOGY}

Present study is a review research and the data was collected online by typing the words "Insanity' "Negligence of Investigative officers" "Mental illness and criminality". Various online search engines were used such as "indiankanoon.com" "Legal Crystal" and High Court's website to collect the judgments. Various government website to collect the acts has been done and relevant acts were obtained. An analytical research has been carried out and appropriate findings were incorporated in the review.

\footnotetext{
6Prins S.J. and L. Draper. 2009. Improving Outcomes for People with Mental Illness Under Community Corrections Supervision: A Guide to Research Informed Policy and Practice

${ }^{7}$ AIR 1966 SC 1631) CRIMINAL APPEAL NO.474 OF 2019
}

\section{Case-I}

A 19 year old spinster girl was charged of murdering her mother and sister on $7^{\text {th }}$ Feb2017. Accused was youngest among all six siblings. Father and most of the siblings were involved in the same business of selling old cloths.She inflicted swordblow on her mother and two sisters during their sleep early in the morning. When she was inflecting blow on sisters she was pushed aside by his elder brother. After reaching to the hospital mother and a sister was declared dead but one sister survived with depth abdominal injuries. The complainant was accused's elder brother during his statement he mentioned that before the day of incident mother scolded and slapped accused on her face over the household chores. During the verbal altercation with mother accused was hurling abusive language.He further statedthat accused was suffering from mental illness for which shewas under treatment since last two years at a private clinic at Gandhidham.

She was arrested and as the case was exclusively session triable came to the session court under the Section 209 Cr.P.C.After the prosecution evidence, the charges were framed and she was convicted and imposed death penalty. The appellant was dissatisfied with judgment and appealed in High Court ${ }^{8}$.

Court observed severe lacuna from law enforcement agencies, judicial magistrate and session judge. Court has pointed out all the failures made on all these three stages of criminal justice. Court also quoted several human right violation issues in this case. Finally,issued direction to the Director General of Police, Gujarat State and all Judicial Magistrate, Session Judges/ Special judges

\footnotetext{
${ }^{8}$ Gujarat vsManjuben, Gujarat High Court, March 18,2019, Retrieved from https://indiankanoon.org/ on $21^{\text {st }}$ May, 2020.
} 
regarding the handling of an accused as follows;

$\checkmark$ If during the arrest of an accused any conduct or history of that person indicating unsoundness of mind is found or noticed. It is the duty of the investigative officer (IO) who has arrested him to produce him before the medical officer for his mental status examination with regard to his mental condition and to obtain the necessary certificate. Same should be produced before the magistrate.

$\checkmark$ If accused person is suffering from any defect of mind, he should be forwarded to a mental hospital for treatment and until certificate of his fitness is received, the matter cannot precede further (Fitness to stand trial).

$\checkmark \quad$ If the IO fails to perform his duty of getting the accused person examined by the medical officer, it is the responsibility of the Judicial Magistrate before whom he is produced for the first time.

$\checkmark$ If he noticed at the time of first remand that there is history of mental illness or signs of the accused showing insanity, he should refer the accused person for medical examination and clarify whether the accused is suffering from mental or legal insanity or not.

$\checkmark \quad$ In case of any mental insanity, he should be provided with appropriate medical care and support.

With these above mentioned directions court has also noted certain limitation during trial and mentioned that Section 304Cr.P.C. is also not been exercised in this case and further stated that it indicates the clear violation of the latter and spirit of Article 2.
In the aforesaid context, Court has also referred to the National Legal Services Authority (NLSA) that provides free and competent legal services and instructed them to provide senior advocates to defend cases of very serious nature, affecting the life and liberty of an individual.

\section{Case-II}

A 36 year old married lady was charged for the killing of 3 people at Kottiyam Police Station Kerala. In the fact of this case on 05/02/2008 at 5:00 pm, accused lady has attacked with knife and slash neck of her mother and two daughters aged 8 and 6 years. Further she inflicted a deep cut on her own neck to commit suicide.The mother was died immediately but both girls and accused were rushed to the hospital by the neighbors. Both the girls were declared dead by the medical officer. However, due to timely medical intervention and care accused survived.

She was arrested and charged for 3 murders. During trial all the evidenced were examined. Accused was also questioned under Sec.313 (1) (b) Cr.P.C. after the closure of the prosecution evidence. Accused denied all the incriminating facts and circumstances. In addition she stated that she had been mentally ill at the time of the incident. She mentioned that somebody had trespassed into her house and attacked on victims she could not harm anybody. Session court found the accused guilty under section 302 \& 309 IPC and sentenced her for life imprisonment.

Defendant has pleaded in the high court against the verdict and in response court stated that in the cases of unsoundness of mind, it is the responsibility of accused to produce evidence $^{9}$ to get benefit under section 84. However, in this case accused was failed to convince the lower courts regarding her mental condition. Defense has argued that

9The Indian Evidence Act 1872 Chapter-VII 
during investigation process it was came to light that accused was suffering from some mental illness but the same was not produced before the court, failure of the proper investigation accused was deprived from the benefit of doubt. High court was convinced with the doubt raised by the defendant that when a lady charged with a murder of her own two children and mother without any strong intention should have indicated doubt in the mind of investigation as well as judiciary ${ }^{10}$. It should be immediately inquired and medical examination of the accused should have been done. That was not happened in this said case which indicates strong weakness and failure from prosecution side. This automatically provide right to get benefit of doubt and acquittal from the criminal responsibility.

In the fact of this case defendant has produce enough evidence that proved that the accused was laboring from delusional disorders since four year before the incident. And after one year of treatment she was diagnosed with schizophrenia. However, any proof of mental state was not produced at the time of crime. Defendant has argued about the infirmity in the investigation and stated that spite of evidence oftreatment for mental disorder which was spoke by the witness (Accused's brother) during prosecution questioning. Investigative officer also admitted during cross examination about the statement of accused brother regarding mental illness. Investigative officer also admitted that medical examiner who examined the accused after the incident advised psychiatric consultation. He also admitted that he has knowledge of the family history of mental illness.

The various aspects highlighted from the evidence was enough to gives rise to a

10 Live Law News 15 Jun 2021 https://hindi.livelaw.in/category/top-stories/keralahigh-court-acquits-accused-in-a-triple-murder-casefor-failure-of-investigation-officer-to-ascertainmental-stability-175738, Accessed on 12 Aug-2021 reasonable doubt about the mental condition of the accused at the time of incident, that entitled her to benefit of the exception.

Court has noticed that if the investigative officer was fair enough and wanted to bring the true facts he would have made and inquiry into the aspect of the mental state of the accused. Peculiar nature of the crime coupled with the factors brought out during investigation ought to have been account. Failure to the same creates serious infirmity in the prosecution that would entitle the accused to benefit of doubt.

\section{Negligence or unawareness amonggeneral population}

Large number of people in India still not consulting hospitals or proper medical practitioners for mental illness either due to unavailability, unawareness or stigma. According to a study conducted in 7 North Indian states by Cosmos Institute of Mental Health and Behavioral Sciences (CIMBS) and $W_{F M H}{ }^{11}$, Nearly half of the population is neither aware about mental health issues nor has access to a mental health facility within a $20 \mathrm{~km}$ radius. There are few more problems related to the issue of treatment and documentation or record keeping that hinders the justice process when comes to providing evidence of undergoing mental illness.

i. Many times if they consult mental health practitioners obtain medicine initially they keep all the records but gradually they tear, missed or destroy it.

ii. Most of the people in the country are still either initially or during full course

\footnotetext{
${ }^{11} \mathrm{http}: / /$ timesofindia.indiatimes.com/articleshow/71 512849.cms?utm_source=contentofinterest\&utm medium=text\&utm_campaign=cppst Accessed on 13Aug-2021
} 
of illness visiting faith healers for treatment of mental illness.

iii. Most of the people either literate or illiterate still believe that there is nothing like mental illness. They strongly believe that these people are doing drama or acting to get some short of benefit or to achieve secondary gain.

iv. Mental illness and psychiatry is still very specialized field in the country. Therefore, knowledge of different mental disorders is limited to the mental health professionals or medical professional.

v. Despite of several efforts from Bauru of Police Research and Development (BPR\&D), and Ministry of Home Affairs (MHA), Government of India to provide training regarding mental illness, most of the law enforcement personnel are still unaware about the mental illnesses. Hence, they are also behaving same as other people of the society towards mental illness.

\section{DISCUSSION}

On the basis of above findings it can be said that law has all the provisions to help a mentally ill person. Either their families are able to support or not system has its own provisions where one can get free legal aid and it is responsibility of the state to make necessary arrangements. India as

\footnotetext{
${ }^{12}$ United Nations. Convention on the Rights of Persons with Disabilities. Geneva: United Nations; 2006.

${ }^{13}$ Kelly B. D. (2016). Mental health, mental illness, and human rights in India and elsewhere: What are we aiming for?. Indian journal of psychiatry, 58 (Suppl 2), S168-S174. https://doi.org/10.4103/00195545.196822 .

${ }^{14}$ Therapeutic jurisprudence is an interdisciplinary method of legal scholarship that aims to reform the law in order to positively impact the psychological
}

permanent member of United Nation has participated in the Convention on the Rights of Persons with Disabilities (CRPD) ${ }^{12}$ which was adapted by the United Nations (UN) in 2006 and ratified by India in $2007^{13}$. MHC Act, 2017 emphasized the need to enhance the level of social justice experienced for the mentally ill people.It also guides and directs the primary and secondary stake holders of the criminal justice system regarding how to deal with a person who seems to be suffering from mental illness or unsoundness of mind. Criminal Justice Procedure are also described that how to deal with a person of mentally ill who comes in conflict with law. However, on the basis of above two cases it can be inferred that still the police officers and the magistrates are not much aware of such mental conditions. And making serious mistakes and violating basic human rights. India as a words highest democratic country need to look into these issues and work on the improvement of human right problems faced by mentally ill people.

\section{CONCLUSION}

After discussion and findings, it has been clear that the training and awareness for the mental illness should be designed and implemented for the basic pillars of criminal justice system. It is also desirable to enact therapeutic jurisprudential ${ }^{14}$ intervention for better outcomes. The other measure such as case management service by mental health professional for liaison will also be benefiting

well-being of the accused person. In 1990, law professors David Wexler and Bruce Winick coined the term "therapeutic jurisprudence" to acknowledge the sociopsychological consequences of any legal action and that these consequences can be impacted by the interpretation of substantive legal rules and procedures. See, Therapeutic Jurisprudence: The Law as a Therapeutic Agent by David Wexler (1990). 
to the trial of psychologically disturbed or unsound accused related cases. In general public and authority, the negative consequences by mental patient and criminal violence must be reduced by awareness programs time to time. Further the proper implementation of the laws and policies should also be look by the government with periodical assessment.

\section{REFERENCES}

1. Mental Health Care Act.2017. Ministry of Law and Justice, New Delhi.

2. The Code of Criminal Procedure, 1973, Ministry of Law and Justice, New Delhi.

3. Gaur J. R. and Tripathi, M. A. "Insanity, mental trauma, crime and the law", International Journal of Management and Social Science Research Review, 8, 12, (2021).

4. Tripathi, M. A. and Tripathi, A. K. Paradigm Shift in Indian Legislature with Reference to Criminal Responsibility of an Unsound Mind, "Pragyaan: Journal of Law" 10, 1, (2020).

5. AIR 1970 All 51, 1970 CriLJ 132.

6. Prins S.J. and L. Draper. 2009. Improving Outcomes for People with Mental Illness Under Community Corrections Supervision: A Guide to Research Informed Policy and Practice.

7. AIR 1966 SC 1631) CRIMINAL APPEAL NO.474 OF 2019.

8. Gujarat vsManjuben, Gujarat High Court, March 18,2019, Retrieved from https://indiankanoon.org/ on 21st May,2020.

9. The Indian Evidence Act 1872 Chapter-VII.

10. Live Law News 15 Jun 2021.

https://hindi.livelaw.in/category/topstories/kerala-high-court-acquits-accusedin-a-triple-murder-case-for-failure-ofinvestigation-officer-to-ascertain-mentalstability-175738, Accessed on 12 Aug-2021.

11. http://timesofindia.indiatimes.com/article show/71512849.cms?utm_source=content ofinterest\&utm medium=text\&utm_cam paign=cppst Accessed on 13Aug-2021.

12. United Nations.Convention on the Rights of Persons with Disabilities. Geneva: United Nations; 2006.

13. Kelly B. D. (2016). Mental health, mental illness, and human rights in India and elsewhere: What are we aiming for?. Indian journal of psychiatry, 58(Suppl 2), S168-S174. https://doi.org/10.4103/00195545.196822.

14. Therapeutic jurisprudence is an interdisciplinary method of legal scholarship that aims to reform the law in order to positively impact the psychological well-being of the accused person. In 1990, law professors David Wexler and Bruce Winick coined the term "therapeutic jurisprudence" to acknowledge the sociopsychological consequences of any legal action and that these consequences can be impacted by the interpretation of substantive legal rules and procedures. See, Therapeutic Jurisprudence: The Law as a Therapeutic Agent by David Wexler (1990). 